\title{
Assessing the role of China in Africa's infrastructure development and its impact on the African continent.
}

\author{
Jean-Marie Mwepu Mbuya \\ Amanda Mphahlele \\ College of Business \& Economics, School of Management \\ Department of Business Management, University of Johannesburg, South Africa
}

\section{Keywords}

Infrastructure, China, development, economic growth

\begin{abstract}
China is one of the fastest growing economies in the world. In 2019, statistics shows that - China's economy grew by 6.3 \%. In addition, it has now become a major development partner for countries throughout the continent, and its trade, investment, diplomatic, and political relationships with sub-Saharan African countries continue to strengthen.

In 2015, foreign direct investments into Africa totalled \$66.4 billion for a total of 705 projects, with infrastructure-related commercial activities like energy, building, and ICT $\mathcal{E}$ internet infrastructure accounting for $13 \%$ of all projects into Africa, and $44 \%$ of capital invested.

This paper aimed to assess the role of China in Africa's infrastructure development and the impact these projects have on the African continent, in order to determine their worth for informed decisions to the governments involved. For this purpose, literature was reviewed and found that, while Chinese projects largely provide job prospects and access to utilities such as electricity, water and etc, working conditions in these projects are very unfavourable with poorly administered policies. The paper proposes proper monitoring and evaluation by relevant government agencies at the sites of constructions.
\end{abstract}

\section{Introduction}

"Africa suffers from poor quality and expensive infrastructure services compared to other parts of the world. It is estimated that this constraints productivity by up to $40 \%$ and reduces the continent's GDP by about 2 percent per year" (Mofor, 2019).

According to Ondiege, Moyo and Chouchane (2013), Infrastructure development is crucial for economic development for any economy. However, African countries are characterised by inadequate infrastructure that have raised the transactions costs of doing business in the continent. This implies that today, African countries exhibit the lowest of productivity of all income countries and are classified under the least competitive economies in the world. Further, Ondiege et al (2013) also indicated that the lack of infrastructure in the African continent is estimated to shave off at least 2 percent of African annual growth. According to a study conducted by the Programme for Infrastructure development in Africa (PIDA), an investment of about 93 billion US dollars is needed until 2020 for both capital and maintenance. Therefore, with the huge investment needed, Governments are required to investigate for innovate and sustainable approaches in order to raise the finances needed to develop and modernise their infrastructure. This implies that with their budgetary ressources, African countries were unable to finance infrastructure projects.

Currently, According to Jayaram, Kassiri \& Sun(2017), over 10,000 Chinese-owned firms are currently operating throughout the African continent, and the value of Chinese business there since 2005 amounts to more than $\$ 2$ trillion, with $\$ 300$ billion in investment currently on the table (China Global Investment Tracker, 2020). To keep this momentum building, Beijing recently announced a $\$ 1$ billion Belt and Road Africa infrastructure development fund (Silk Road Briefing, 2019)and, in 2018, a whopping $\$ 60$ billion African aid package,(Sow, 2018), with several other developments that were stopped due to Covid- 
19 in 2019 and 2020. As a result, Africa's pull to the east is expected to continue as commercial relations with China become more widespread and robust.

\section{The problem}

As indicated earlier, Chinese investment play a crucial in infrastructure development in the African continent over the past years. African governments are therefore able to collaborate with Chinese government on various project in exchange of mineral ressources or other related benefits. However, the challenge remains the fact the Chinese companies are now taking total control of the African market, and this is negatively affecting local business development. In addition, most of the African government do not have systems and measures in place to actually evaluate the quality of the work delivered by the Chinese partners and this end up not to be a win-win situation for African countries.

\section{Methodology}

The research followed a qualitative approach and made use of secondary sources in the form of reports, journal articles and other case studies on focusing on China's involvement in Africa infrastructure development.

\section{Research objective}

This research aims to assess China's involvement in developing Africa's infrastructure by means of reviewing various studies done in Africa over the past years. In addition, the research aims to provide recommendations to stakeholders and policymakers based on findings of the different research that have been done.

\section{Literature review}

\section{The state of African Infrastructure}

In the African context, developing infrastructure is crucial in order to alleviate the high-rate poverty that the continent is experiencing (Khumalo, 2013:5644). According to Stachtebeck and Mbuya (2016), infrastructure development plays an important role in both rural and urban areas. In rural areas, infrastructure development can boost agricultural production and commercialisation. Further, Mesegan and Bello (2018) also point out the fact that an adequate supply of infrastructure services is a key requirement for the structural transformation of any economy from the production of primary products to the secondary services. Therefore, a reliable transport network can significantly reduce the high cost associated with the shipping of agricultural product as well as improving access to arable land. In addition, economic interactions are in much closer proximity in urban areas, as this enables more efficient use of space due to ease of access to nearby public facilities, job opportunities and housing.

The word Infrastructure originates from Latin, and namely the word" infra" is understood as grounds or fundamentals while " structure" refers to distribution of elements of certain undefined setup. Infrastructure is the basic systems and services, such as transport and power supplies that, a country or organisation uses in order to work effectively. Infrastructure is a component of the territorial structure of national economy, which is formed by the transport, communications, trade, energy and water management systems as well as dwellings, schools, objects of health protection, culture, sports and other objects for the wellbeing of inhabitants and their arrangement in any territory (Skorobogatova \& Merlimo,2017).

According to Azam and Bakar (2017), infrastructure can be classified into two broad categories namely, economic infrastructure and social infrastructure. Economic infrastructure comprises transport and communication, irrigation, energy, banking ect., whereas social infrastructure comprises sectors such as housing, health, education ect. The level of development of the different areas influences infrastructure development. Therefore, it can be argued that the improvement of infrastructural services is crucial in order to enhance efficiency of the productive process and to raise productivity of any economic entity.

Kauffman (2008) stated that the lack of adequate infrastructure has important direct and indirect human implications and negatively impact of business development. In her study titled " Engaging the Private Sector in African Infrastructure", the authors also reported that due to the lack of infrastructure, 
the cost of doing business in the African continent was 30\% higher than in other region, with high level of indirect expenses estimated to 20 to $30 \%$ of the cost. Some of the factors identified by the authors that caused this situation included economic legislation and weak legal systems, inadequate infrastructure ect. Further. Kauffman (2008) also stated that investment in infrastructure related projects is highly capital intensive associated with long payback periods with disparate commercial rates of return across sectors. It has been reported that Bank rates ranges from 5 to $10 \%$ in the water sector, $17-25 \%$ in the power sector and nearly 25 to $30 \%$ in the telecoms sector. Therefore, this profile generates high contractual and risks in the context of political instability.

\section{Chinese Infrastructure Investments in Africa}

Kirchhner, Disselhoff and Charles (2016) stated that China is a major investor in Africa's infrastructure. It has been reported that China's investment is estimated to approximately two-thirds of the total infrastructure investments since 2007. In addition, it has also been reported that about $16 \%$ of China's foreign direct investment in the African continent is directed to infrastructure with an estimated $31 \%$ in mining, a $20 \%$ into the finance industry. However, it has been reported that the majority of investment are focusing on the power sector.

Some examples of Chinese investment in Africa include the following namely, The Tanzania-Zambia railway with $1800 \mathrm{~km}$; the project costed nearly USD 450 million. In Addition, roads, wells and telecommunication facilities were also among the projects done. The Caxito irrigation projects in Angola (2007-2010), the Kuito Water supply in Angola ect. Other example of Chinese infrastructure project in Africa includes Senegal; the Dakar Container Terminal and the Main one Cable System. It is important to note that the Main one Cable System is crucial in the way that it was aimed to improve Internet access at lower cost in West Africa (Schiere \& Rugamba,2011) to name a few.

One may ask why China seems to be succeeding as a primary financier of infrastructure development in projects in Africa with loans estimated to approximately 6.5 billion US dolars Bosshard (2007). Reality is, the Chinese government noticed that Africa's most pressing need is infrastructure, but it is unaffordable to the continent as a whole, even if they join forces. According to the recent World Finance projections, Africa's countries will need to invest \$130-170 billion each year on infrastructure to meet their needs (Ballard 2018). However, the African Development Bank estimates that they will fall short by $\$ 68$ $\$ 108$ billion (WallStreet, 2018).

Also, many African contractors simply lack the capacity for large-scale development projects, so when it comes to conducting large-scale construction, is either the western firms or the Chinese firm, but the Chinese firm are always able to offer lower prices. Hence, China has been the most important actor in Africa's infrastructure development since 2011, with a $40 \%$ share that is still growing. Meanwhile, other players' shares are plummeting Europe's stake has dropped from $44 \%$ to $34 \%$, while the participation of US contractors has dropped from $24 \%$ to only 6.7 percent. See figure 1 which indicates China's share in the African development market against other counties around the world.

Scholars also argue that China's model of investment in the Africa continent is far different from the western traditional partners. No wonder it has overtaken the United States and Europe as Africa's most important trading partner, with huge shares in Africa's construction market, see figure 1 . And today most African countries have huge trade deficits with China, selling resources and purchasing manufactured commodities from the Chinese Adisu \& Sharkey (2010) stated that China's approach in relationship with African government was unique; the authors further explained that their approach is not to get involved with local politics of the country there are interested in. Western governments often provide financial or material aid to African countries, which some contend is only a bandage over complex and entrenched structural problems. Clearly, this method has failed to result in Africa's inclusive and long-term growth (Brown, 2018). Also, this means that factors such as democracy, good governance and poverty reduction to name a few are not part of their agenda when investing in Africa. Whereas the West prefers to impose values on the countries it aids (often in accordance with foreign policy aims), China is all about business transactions. China's government does not impose its political or foreign policy objectives on African nations. Focusing solely on business and investment, Africans are more welcoming of China's presence, as 
it is in many ways the polar opposite of Western governments' neocolonial mindset, which seeks to actively participate in local African affairs (Brown, 2018)

Rather, Chinese model of investment in Africa focus on assisting African government in developing their infrastructure in exchange of rich natural resources found in the continent. For instance, Africa provides about a third of China's oil, as well as $20 \%$ of the country's cotton. Africa holds about half of the world's manganese reserves, a crucial component of steel production, while the Democratic Republic of the Congo alone holds half of the world's cobalt reserves (Shepard, 2019). Africa also possesses a large supply of coltan, which is used in electronics, as well as half of the world's known supply of carbonatites, which are the principal source of rare earths (Herskovitz, 2011).

Example of this model can be seen in countries such Angola, where Chinese secured a US 2 billion dollars in aid for infrastructure projects, thereby securing a form shell oil block in Angola by outbidding an offer from the Indian Government. In line with the investment in Angola, China also promised US 7 billion in investments and rehabilitation of power stations to secure an oil investment from the western investment. One important benefit that African government get from the new Chinese partners is the fact that their investment does not require a package of reform usually required by the World Bank under its "Conditionality provisions". Therefore, it can be argued that Chinese investment come with "no strings attached" and a crucial for African governments in need of ressources for their development.

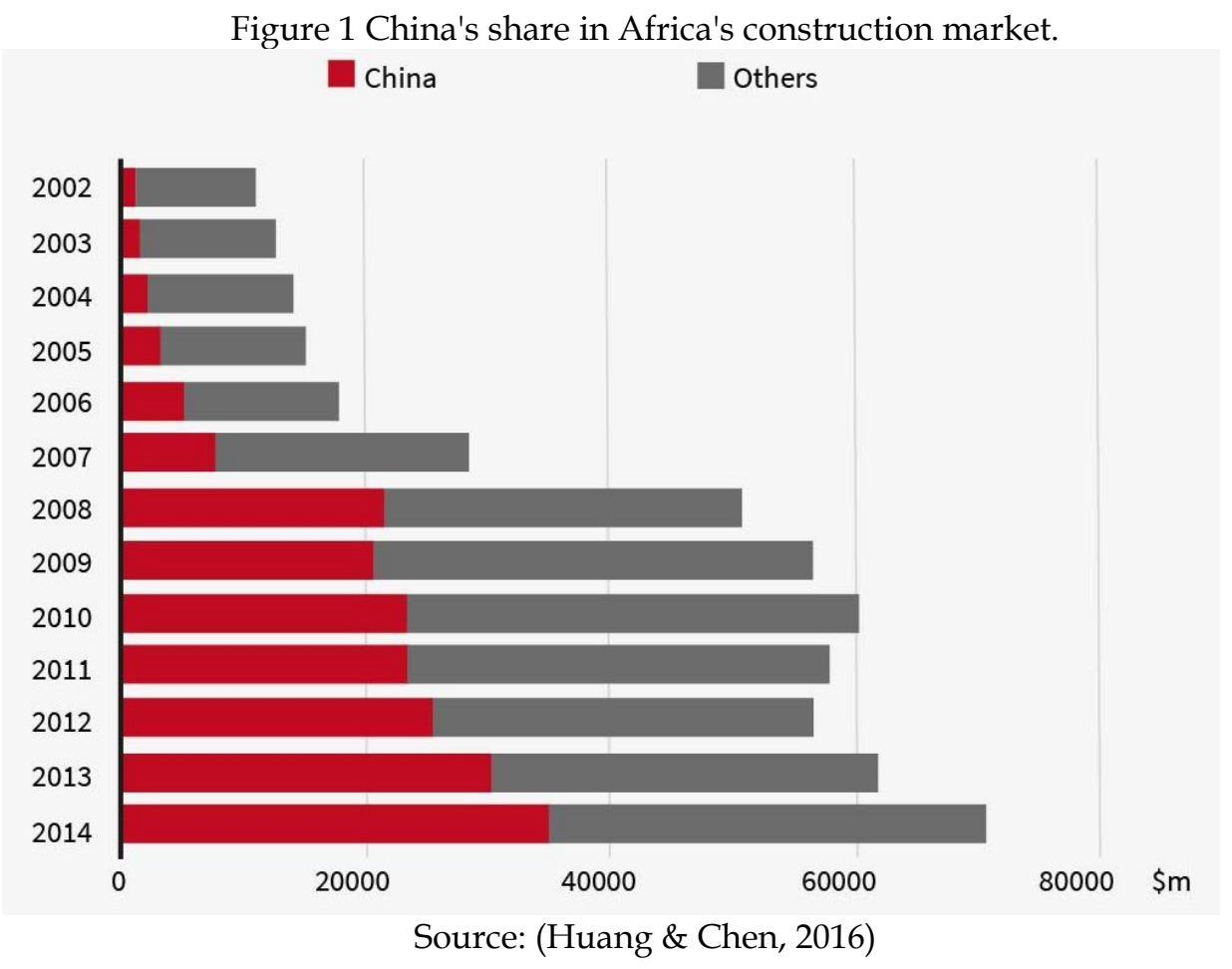

Another reason that makes Africa is a more fertile ground for such investments is that it has the highest population growth potential of any continent on the planet. The continent, which already has the world's youngest and fastest-growing population, is urbanizing at a faster rate than any other portion of the globe. The world economic Forum on Africa of 2016 in Kigali Rwanda, it was predicted that the population is expected to double by 2050 . More than $80 \%$ of that growth will occur in cities, especially slums (Muggan \& Kicullen, 2016).

It's no surprise that China wants to take advantage of some of Africa's fastest-growing economies. Countries, such as Kenya and Ghana, are experiencing a growing middle class, resulting in a rise in consumerism. Africa's expanding consumer class is particularly appealing This is beneficial to Chinese 
producers (Brown, 2018), considering a drop in demand for Chinese goods in Europe and the United States illustrated in table 1, beaten 2014 and 2015 (UNCRAD, 2016).

Table 1: Table 2: Changes in the value of the largest bilateral trade flows between 2014 and 2015, by product group: Manufacturing

\begin{tabular}{|l|l|l|l|}
\hline $\begin{array}{l}\text { Exporter } \\
\text { Billion) }\end{array}$ & Importer & Change 2014 vs 2015 (\%) & Value in 2015 (US\$ Billion) \\
\hline European Union & China & $-15 \%$ & 191 \\
\hline European Union & European Union & $-12 \%$ & 2320 \\
\hline United States & Canada & $-8 \%$ & 173 \\
\hline China & European Union & $-6 \%$ & 417 \\
\hline Canada & United States & $-3 \%$ & 183 \\
\hline China & Hong Kong S.A.R. & $-3 \%$ & 249 \\
\hline China & United States & $3 \%$ & 490 \\
\hline European Union & United States & $3 \%$ & 371 \\
\hline Mexico & United States & $7 \%$ & 251 \\
\hline United States & European Union & $9 \%$ & 288 \\
\hline
\end{tabular}

Source: UNCTAD 2016 ( calculations based on Comtrade data.

\section{The impact of Chinese investment in Africa}

The involvement of China in African development has since been perceived with mixed feelings. While it is perceived with skepticism due several issues, there're are those who welcome the interventions as optimistic for African development (Alden, 2005), only a strategic vision needs to be developed, for the continent to optimally benefit from the Chines investments (Schiere \& Rugamba, 2011), as similar to the neo-colonialism of the past (De Lorenzo, 2007).

\section{Labour market and socio-economic factors}

Although in the early 2000s it was perceived that Chinese firms employ less locals, things seem to changing. For instance, over the last five years, the number of Chinese laborers in Africa has decreased by 30.7 percent. The Chinese labor force in Africa has been steadily declining since 2015, when it peaked at 263,659 people (Idris, 2021). Resent research conducted by the Industrial Development, Construction and Employment in Africa (IDCEA) in Angola and Ethiopia also confirmed growth in localization rates, for instance, rates were $90 \%$ for all workers in Ethiopia, and 100\% for low-skilled workers, and 74 percent in Angola, where rates are often significantly lower due to skill shortages (Oya and schaifer 2019). Similarly, Kirchher, Disselhoff \& Charles (2016) indicated that only 2 out 10 workers hired during the Bui dam construction in Ghana were Chinese. While the total number of Chinese workers in Africa is generally declining, some countries, such as Guinea, Mauritania, Uganda and Zimbabwe, are seeing an increase (Ani, 2020). For instance, Zimbabwe had at least 10,000 Chinese residents, the majority of whom work in the mining, telecom, and construction industries. The presence of such a high number of Chinese people in the country causes tensions among locals (ANI, 2021).

In addition to increasing employment prospects for locals, he contracted projects have contributed to the transfer of technical and management skills from Chinese specialists to African workers (Baah and Jauch, 2009). As a result, some residents have established their own construction firms. However, there are other labor relations and employee wellness issues, which these firms allegedly ignore. There is consistently great concern about working conditions in Chinese enterprises (Laryea and Mensah (2010). And most often, improvements are only implemented if workers and trade unions protest (Kirchher, Disselhoff \& Charles 2016). In 2019 the Zimbabwe Environmental Lawyers Association (ZELA) exposed rampant abuse local workers experience, to an extend that the assassination advised the government to reconsider the country's relationship with China (ANI, 2020).

In some cases, local workers are not given contracts of employment, because for some reasons Chinese authorities do not expect to find organized labour in Africa (Baah and Jauch 2009). It is reported 
that Chinese authorities when establishing a project in Arica, the "implement industrial revolution capitalism" Kirchher, Disselhoff \& Charles 2016:5),make it difficult for labour union formation, and pose threats and intimidation whenever workers try to challenge their systems ( Hensengerth, 2011). Further allegations include dismissing workers absent on health grounds, not proving workers with safety uniform, physically abusing workers. While other workers were sleeping on the bare floor because of shortage of mattresses, The project manager commented that "After all, some of them are living in better accommodation here than most of the villagers around," (The Ghanaian Times, 2008). More health and safety concerns were raised by Laryea and Mensah (2010), after investigating 14 construction sites of different Chinese projects in Ghana. Though health and safety policies were in place to ensure some form of structure for assuring health and safety on the job, the data showed that there was a significant disparity between what is stated in the policy and what actually occurs in practice. Contractors did not implement the majority of the policy's provisions on the job site. Some of the key motives behind these actions were found be maximization of profits to make the most money possible, as well as the lack of substantial penalties for health and safety offenses. These scenarios indicate a gab when it comes to monitoring and evaluation in other African countries.

Concerning trade and business, recipient African countries have benefited from investment inflows, however, there have been certain downsides. They have, for example, had a negative impact on local trade and business. Furthermore, Chinese investment has not always befited African workers. (Adisu, Sharkey \& Okoroafo, 2010). China been accused of only concerned about the globalization of Chinese construction and IT corporations, as well as the development of infrastructure to better exploit and export African resources. (Shepard, 2019)

Socially, in many countries, people's lives were positively impacted, mostly in urban areas. For instance, hydropower infrastructure made electricity more accessible (Tang and Shen, 2020). However, lack of social safeguards is a major accusation leveled against Chinese players in Africa. Local rules and regulations are often underdeveloped, if not non-existent, in many developing markets. Kirchher, Disselhoff, and Charles (2016), for example, criticized Chinese participants for the lack of an effective consultation process during the construction of the Bui Dam in Ghana. "Constructors had no idea when they would be relocated, when they would be compensated, or how to express their dissatisfaction" (Kirchher, Disselhoff \& Charles 2016:41). Scholars examining Chinese dam projects in the Mekong River Basin agree with this conclusion about roles and duties in dam development (Matthews and Motta, 2013). Another concerning issue is the threat of transmission of diseases among workers. Though workers employed in Chinese projects come from local areas, usually due to insufficient skills at the immediate regions, most of them come from outside the construction area (Baah and Jauch, 2009) This inflow of labor will almost certainly have social consequences. Large influxes of laborers from other zones are typically linked to an increase in prostitution and the spread of diseases (Lerer and Scudder, 1999).

\section{Indebtedness}

When we look at Africa, we see many countries chasing aspirations of a brighter economic future while burying themselves in tremendous infrastructure-related debt that they may not be able to repay. There were previously warning signs: Ethiopia's \$4 Addis Ababa-Djibouti Railway cost roughly a fourth of the country's total 2016 budget. Nigeria had to renegotiate a contract with their Chinese contractor when they failed to pay, while in 2017 in Kenya's 80 percent Chinese-financed railway from Mombasa to Nairobi is already four times over budget, costing the country upwards of 6\% of GDP (Pheiffer, 2017). According to the IMF, China owned 15\% of Africa's external debt in 2012, yet just three years later, China accounted for roughly two-thirds of all extra loans (Brown 2018). As a result, some analysts are predicting debt traps, while others are calling China's efforts a new type of colonialism.

\section{Conclusion and managerial implications}

From the above, it can be argued that China plays a crucial role in Africa's infrastructure development. Having good infrastructure in Africa is crucial in order to develop the private sector but also challenges related to poverty and inequality. However, a number of studies have criticised China 
investment model in Africa in a number of ways. For instance, a study conducted by Chen (2009) highlighted the fact that infrastructure related project done by Chinese companies were not of good quality; this evidence was obtained from officials in Botswana who pointed out some irregularities in some of the work done.

In absolute terms, China has been the biggest contributor to job creation, particularly in recent years, despite raised labour relations issues. It has been recorded that some African countries do have good labour relations legislations, however, these laws are not enforced at construction sites at all, or except by the intervention of labour unions. Therefore, responsible government agencies should ensure proper monitoring and evaluation at these sites. Chinese partners had the tendency of bringing their own labour directly from China instead of favouring local labour. Though in recent years a change has been detected, some areas still experience the concentrations, which create tensions among workers. Social responsibility, language and cultural differences have also been highlighted as problems. In order to avoid disappointment, African government should agree with the Chinese partners on clear deliverables for the various projects and put in place mechanisms to ensure that the partnership results on a win-win outcome beneficial for both. In addition, a third-party partner should also be involved in order to provide his expertise on the quality of the various projects.

\section{References}

Adisu, K and Sharkey T (2010). The impact of Chinese Investment in Africa. International Journal of Business Management. 5 (9): 3-9

Alden, C. (2005). China and Africa. Survival, 47(3), 147-164.

Baah, A.Y. and Jauch, H., 2009. Chinese investments in Africa: A labour perspective. African Labour Research Network.

Bosshard, P (2007). China's role in Financing Africa Infrastructure. International Rivers report.

Chen, A.Y (2009). China's role in Infrastructure development in Botswana. Working paper. African perspectives.

De Lorenzo, M. (2007). African Perspective on China. American Enterprise Institute for Public Policy Research, Wed. October 3, 2007.

Hensengerth, O., 2014. Interaction of Chinese institutions with host governments in dam construction: the Bui Dam in Ghana. In Evolution of Dam Policies (pp. 229-271). Springer, Berlin, Heidelberg.

Kauffman, C (2012). Engaging the private sector in Africa Infrastructure. Investment and transport infrastructure.

Kirchherr, J, Disselhoff, T and Charles, K (2016). Safeguards, financing and employment in Chinese infrastructure projects in Africa: the case of Ghana's Bui Dam. 31(1): 38-58.

Moyo, L (2020). Africa has a 100 billion Infrastructure problem. What is missing? Available from https://www.brinknews.com/africa-has-a-100-billion-infrastructure-problem-whats-missing/

Laryea, S. (2010) Health and safety on construction sites in Ghana. In: The Construction, Building and Real Estate Research Conference of the Royal Institution of Chartered Surveyors, 2-3 September 2010, Dauphine Université, Paris, France. Available at http://centaur.reading.ac.uk/16289/ [ accessed 28 June 2021]

Lerer, L.B. and Scudder, T. (1999) 'Health impacts of large dams', Environmental Impact Assessment Review 19(2): 113-23 <http://www.sciencedirect.com/science/article/pii/S0195925598000419>.

Matthews, N. and Motta, S. (2013) China's Influence on Hydropower Development in the Lancang River and Mekong River Basin [pdf], State of Knowledge Series 4, Vientiane, Lao PDR: Challenge Program on Water and Food $<$ https://cgspace.cgiar.org/bitstream/handle/10568/35102/Chinainfluence-_Eng.pdf?sequence=1> [accessed 20 June 20121].

Skororobogotova, O and Merlino, I.K (2017). Transport Infrastructure Development performance. $16^{\text {th }}$ Conference on Reliability and statics in transportation and communication. 178: 319-329.

Odienge, P, Moyo, JM and Chouchane, AV (2013). Developing Africa's Infrastructure for enhanced competitiveness. The Africa competitiveness report

Oya, C. and Schaefer, F., 2019. Chinese firms and employment dynamics in Africa: A comparative analysis. IDCEA Synthesis Report.

Schiere, R. and Rugamba, A., 2011. Chinese infrastructure investments and African integration. African development Bank Group, Series $N^{\circ} 127$, Tunis, Tunisia.

Shinn, D.H., 2016. The Environmental Imact of China's Investment in Africa. Cornell Int'l LJ, 49, p.25.

Tang, K. and Shen, Y., 2020. Do China-financed dams in Sub-Saharan Africa improve the region's social welfare? A case study of the impacts of Ghana's Bui Dam. Energy Policy, 136, p.111062.

The Ghanaian Times (2008) ‘Ghanaians working on Bui Dam clash with employers' [online], 
Modern Ghana <www.modernghana.com/news/167064/1/ghanaians-working-on-bui-damclashwith-employers.html> [accessed 28 June 2021].

Xiaoyang, T. and Sun, I.Y., 2016. Social responsibility or development responsibility-what is the environmental impact of Chinese investments in Africa: What are its drivers, and what are the possibilities for action. Cornell international Law Journal: 9 (1) 3 